\title{
PENGARUH VARIABEL MAKROEKONOMI TERHADAP JAKARTA ISLAMIC INDEX (JII) PERIODE JANUARI 2004 HINGGA DESEMBER 2017
}

\author{
Rubina Dwi Ghassani \\ Departemen Ekonomi Syariah-Fakultas Ekonomi dan Bisnis-Universitas Airlangga \\ Email: rubina-dwi-ghassani-2014@feb.unair.ac.id

\section{Raditya Sukmana} \\ Departemen Ekonomi Syariah-Fakultas Ekonomi dan Bisnis-Universitas Airlangga \\ Email: Raditya-s@feb.unair@ac.id
}

\begin{abstract}
:
This study aims to determine the effect of Macroeconomic Variables against the sharia stock index, Jakarta Islamic Index. The approach used is quantitative by using the Vector Error Correction Model (VECM) analysis technique with the STATA program. While the Exchange Rates, Industrial Production Index and Money Supply as dependent variables and Jakarta Islamic Index (JII) as the independent variable. Secondary data are used in this research from the official website of Bank Indonesia, Badan Pusat Statistik and Bursa Efek Indonesia. The results of the research shows that the Exchange Rates, Industrial Production Index and Money Supply partially has positive and significant influent against sharia stock index in Jakarta Islamic Index (JII) di Jakarta Islamic Index on the research period is from 2004 to 2017.
\end{abstract}

Keywords: Exchange Rates, Industrial Production Index, Money Supply and Jakarta Islamic Index (JII)

\section{PENDAHULUAN}

Pasar keuangan merupakan komponen penting suatu negara. Pasar Keuangan di negara memiliki fungsi sebagai alat pemindahan dana dari pihak - pihak yang mempunyai dana yang berlebih dengan pihak yang sedang membutuhkan dana. Berdasarkan karakteristik jatun temponya pasar keuangan dibagi menjadi dua yaitu pasar vang dan pasar modal. Secara sederhana menurut Mishkin (2008) pasar vang (money market) merupakan pasar keuangan di mana instrument utang jangka pendek diperjual belikan. Sedangkan pasar modal (capital market) merupakan pasar yang memperjual belikan utang jangka panjang atau jangka waktu jatuh tempo hingga satu tahun atau lebih. Pasar vang jangka pendek cenderung lebih likuid karena lebih sering diperjual belikan dibandingkan dengan pasar modal. Sekuritas yang termasuk dalam pasar modal seperti obligasi jangka panjang dan saham sering dimiliki oleh perantara keuangan seperti perusahaan asuransi dan dana pension yang memiliki sedikit ketidakpastian mengenai nilai dana yang harus mereka sediakan di masa yang akan datang. Indonesia dapat dikategorikan sebagai negara yang memiliki perkembangan paasr modal secara pesat. Namun, kenyataan yang ada pasar modal masih memiliki kerentanan terhadap variabel-variabel makroekonomi global secara umum. Seperti krisis Tom Yam Gung di Thailand

1) Jurnal ini merupakan bagian dari skripsi Rubina Dwi Ghassani, NIM: 041411433027, yang diuji pada tanggal 18 Januari 2019. 
Ghassani, et al/Jurnal Ekonomi Syariah Teori dan Terapan Vol. 6 No. 2 Februari 2019: 372-385; PENGARUH VARIABEL MAKROEKONOMI TERHADAP JAKARTA ISLAMIC INDEX (JII) PERIODEJANUARI 2004 HINGGA DESEMBER 2017

yang menyebabkan menurunnya nilai rupiah yang disebabkan oleh devaluasi, inflasi, dan meningkatnya harga kebutuhan pokok seperti bahan makanan yang mengakibatkan kekacauan sehingga menjadikan Indonesia sebagai salah satu negara yang terkena dampak krisis terparah. Selain itu fenomena krisis.

Subprime Mortage di Amerika Serikat pada tahun 2008 juga berdampak pada Indonesia. Melemahnya mata vang rupiah terhadap dollar hingga mencapai Rp. 12.900/USD yang kemudian memberikan efek negatif pada kegiatan impor di Indonesia. Kemudian pada sektor produksi Di sektor produksi, mereka bersaing dengan kenaikan harga pada faktor input, tetapi dari peningkatan hutang luar negeri dalam satuan dollar Amerika. Dampak yang terakhir yaitu, penjualan saham dan obligasi di AS dan Eropa juga mempengaruhi Indonesia. Kepemilikan atas Surat Utang Negara (SUN) dan Sertifikat Bank Indonesia (SBI) menurun tajam pada bulan Juli dan Agustus.

Kepemilikan saham oleh investor asing selalu mengalami peningkatan. Berdasarkan data dari Bursa Efek Indonesia peningkatan itu terjadi pada tahun 2017 hingga mencapai Rp. 1.878 triliun atau angka tersebut meningkat dari tahun 2016 yang jumlahnya Rp. 1.691 triliun. (republika.co.id). oleh karena itu, bursa saham masih rentan menghadapi kondisi perekonomian global yang sedang resesi (Thobarry, 2009). Dengan adanya krisis finansial yang terjadi akan berdampak pada meningkatnya suku bunga acuan karena nilai rupiah yang melemah terhadap dollar AS kemudian mendorong Bank Indonesia dalam menaikkan suku bunga acuan yang berfungsi sebagai pondasi rupiah agar tidak terdepresiasi terlalu besar (Thobarry, 2009).

Dengan meningkatnya suku bunga akan menyebabkan indeks harga saham konvensional di pasar modal akan turun dan membuat para investor tidak mempercayai kinerja saham-saham yang ada. Oleh karena itu diperlukannya alternatif dalam rangka menyeimbangkan kegiatan di pasar modal sehingga diperlukannya sebuah instrumen saham syariah.

Islam merupakan agama yang sempurna. Segala bentuk kegiatan di muka bumi telah diatur sedemikian rupa oleh Allah SWT. Sebagai umat muslim, diwajibkan untuk mengikuti segala bentuk perintah dan larangan untuk memperoleh ridha-Nya. Termasuk dalam penggunaan harta investasi harus sesuai dengan kaidah Islam.

Firman Allah SWT dalam Surah Al Baqarah ayat 261:

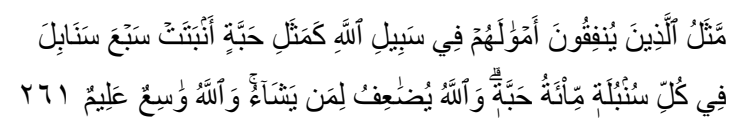
"Perumpamaan (nafkah yang dikeluarkan oleh) orang-orang yang menafkahkan hartanya di jalan Allah adalah serupa dengan sebutir benih yang menumbuhkan tujuh bulir, pada tiap-tiap bulir seratus biji. Allah melipat gandakan (ganjaran) bagi siapa yang Dia 
Ghassani, et al/Jurnal Ekonomi Syariah Teori dan Terapan Vol. 6 No. 2 Februari 2019: 372-385; PENGARUH VARIABEL MAKROEKONOMI TERHADAP JAKARTA ISLAMIC INDEX (JII) PERIODEJANUARI 2004 HINGGA DESEMBER 2017

kehendaki. Dan Allah Maha Luas (karuniaNya) lagi Maha Mengetahui".

Ayat diatas menjelaskan bahwa Allah memerintahkan kepada manussia untuk menggunakan uang atau hartanya di jalan Allah, termasuk dalam kegiatan investasi menggunakan saham syariah. Karena di dalam instrument saham syariah, ada kaidah yang berisi laranganlarangan yang membawa kepada kemudharatan.

Jakarta Islamic Index adalah salah satu indeks yang digunakan untuk menghitung indeks dari harga rata-rata saham untujk jenis saham yang memenuhi kaidah syariah. saham yang masuk kedalam JII telah memenuhi proses pemilihan yang panjang. Proses yang detail dan memperhatikan aspek kehalalan pada pemilihan kinerja suatu investasi pada saham syariah membuat JII dipersiapkan sebagai benchmark (tolak ukur). Saham yang terpilih setiap periode di batasi dengan jumlah 30 saham yang memenuhi kaidah syariah. Melalui JII diharapkan dapat meningkatkan kepercayaan investor untuk mengembangkan investasi dalam ekuitas syariah, dan memudahkan investor dalam memilih investasi di pasar modal. Dengan memilih 30 saham yang ada di Jll investor menjadi tidak ragu untuk berinvestasi bukan hanya dari kehalalannya namun segi likuiditas nilai saham terbesar dalam satu tahun terakhir.

Dengan adanya krisis yang terjadi pada tahun 2008 membuat pergerakan harga saham di Indonesia, khususnya JII mengalami kemerosotan. Hal tersebut menjadi suatu pernyataan bahwa pergerakan harga saham tidak mungkin lepas dari adanya sebab-akibat yang dihasilkan dari variabel makroekonomi. Variabel makroekonomi yang digunakan dalam penelitian ini adalah Nilai Tukar, Indeks Produksi Industri dan Jumlah Uang Beredar.

\section{LANDASAN TEORI}

Menurut M.A. Mannan (1993) dalam penelitiannya yang berjudul "Understanding Islamic Finance: A Study of the Securities Market in an Islamic Framework" hadirnya Pasar Modal Syariah dapat menjadi evaluasi praktir pasar modal konvensional yang bertentangan dengan prinsip syariah. begitu pula di Indonesia, kehadiran pasar modal berbasis syariah di Indonesia diharapkan dapat membantu bank dan asuransi syariah mengoptimalkan penggunakaan sumber dana yang tersedia sesuai dengan prinsip syariah dan menjaga keseimbangan antara likuiditas dan tingkat keuntungan. Transaksi di dalam pasar modal menurut prinsip hukum syariah diperbolehkan selama tidak ditemukannya transaksi yang bertentangan dengan ketentuan yang telah ditentukan nilai syariatnya.

Jakarta Islamic Index atau masyarakat mengenalnya dengan JII merupakan sebuah index yang berfungsi sebagai tolak ukur (benchmark) harga rata-rata saham yang memenuhi kriteria syariah. JII diluncurkan pada tanggal 3 Juli 2000 dan merupakan hasil dari kerjasama 
Ghassani, et al/Jurnal Ekonomi Syariah Teori dan Terapan Vol. 6 No. 2 Februari 2019: 372-385; PENGARUH VARIABEL MAKROEKONOMI TERHADAP JAKARTA ISLAMIC INDEX (JII) PERIODEJANUARI 2004 HINGGA DESEMBER 2017

antara PT. Bursa Efek Jakarta (BEJ) dengan PT. Dana Reksa Investmen Management (DIM) yang bertujuan untuk menampung para investor yang ingin menanamkan modalnya secara syariah. Pembentukan JII merupakan suatu bentuk dukungan dalam pembentukan Pasar Modal Syariah yang diluncurkan pada bulan Maret 2003. Penentuan kriteria dalam pemilihan saham dalam JII dilakukan dengan selektif dan memiliki syarat - syarat tertentu. Adapun saham yang termasuk kedalam indeks JII adalah emiten yang kegiatan bisnisnya tidak melanggar aturan syariah, seperti:

a. Usaha perjudian dan perdagangan yang dilarang.

b. Usaha lembaga keuangan konvensional yang terdapat riba didalamnya (perbankan maupun asuransi konvensional).

c. Usaha yang memproduksi, mendistribusi dan memperdagangkan makanan ataupun minuman haram.

d. Usaha yang menyediakan barang atau jasa yang bersifat mudharat.

Setelah penentuan kriteria pemilihan saham dilakukan kemudian dilanjutkan dengan proses pemilihan saham yang termasuk dalam JII, Bursa Efek Indonesia melakukan tahap eliminasi yang mempertimbangkan aspek likuiditas dan kondisi kevangan emiten, sebagai berikut:

a. Jenis usaha yang sudah tercatat lebih dari 3 bulan menjalani transaksi secara syariah. b. Memilih saham berdasarkan laporan keuangan tahunan atau tengah tahun berakhir yang memiliki rasio kewajiban maksimal sebesar $90 \%$.

c. Memilih 60 saham dari susunan saham diatas berdasarkan urutan rata - rata kapitalisasi pasar (market capitalization) terbesar selama satu tahun terakhir.

d. Memilih 30 saham dengan berdasarkan urutan likuiditas ratarata nilai perdagangan regular selama satu tahun. Serta pengkajian ulang akan dilakukan setiap 6 bulan sekali dan jenis usaha pada setiap emiten akan dipantau secara terus - menerus berdasarkan data public yang tersedia.

Nilai tukar menjadi komponen wajib dalam perdagangan global karena masing - masing negara memiliki mata vang yang berbeda-beda. Sedangkan kurs merupakan harga yang harus dibayar oleh mata uang suatu negara untuk memperoleh mata vang negara lain. Kurs valuta asing dapat didefinisikan sebagai jumlah vang domestic yang dibutuhkan, yaitu banyaknya rupiah yang dibutuhkan untuk memperoleh satu unit mata uang asing. Menurut Krugman dan Obstfield (1999:329) nilai tukar adalah "the price of one currency in terms of another" atau harga satu mata vang terhadap mata vang dari negara lain. Sehingga nilai tukar merupakan salah satu harga terpenting dalam perekonomian terbuka karena 
Ghassani, et al/Jurnal Ekonomi Syariah Teori dan Terapan Vol. 6 No. 2 Februari 2019: 372-385; PENGARUH VARIABEL MAKROEKONOMI TERHADAP JAKARTA ISLAMIC INDEX (JII) PERIODEJANUARI 2004 HINGGA DESEMBER 2017

memiliki pengaruh yang besar terhadap transaksi neraca berjalan maupun variabel-variabel makro lainnya.

Ada beberapa sistem nilai tukar mata uang yang berlaku dalam perekonomian Internasional menurut Kuncoro (2001:26-31), antara lain:

a. Sistem mengambang (floating exchange rate)

b. Sistem tertambat (paged exchange rate) Sistem tertambat merangkak (crawling page). Pada sistem ini suatu negara melakukan sedikit perubahan dalam nilai mata vangnya secara periodic dengan tujuan untuk bergerak menuju nilai tertentu pada rentang waktu tertentu.

c. Sistem sekeranjang mata vang (baskert of currencies).

d. Sistem nilai mata vang tetap (fixed exchange rate).

Faktor - faktor yang dapat mempengaruhi nilai tukar pada suatu negara:

a. Perubahan dalam cita rasa masyarakat

b. Perubahan harga barang ekspor dan impor

c. Kenaikan harga secara umum (inflasi)

d. Perubahan suku bunga dan tingkat pengembalian Investasi

e. Pertumbuhan ekonomi Jumlah uang beredar merupakan suatu stok yang dirumuskan secara sempit (M) meliputi vang kartal dan deposito yang dapat digunakan sebagai alat tukar. Perkembangan pasar vang membuat makin meluasnya pengertian M1. Jumlah uang beredar didefinisikan sebagai M1, M2 dan M3. M2 merupakan komponen M1 ditambah dengan tabungan dan segala jenis deposito berjangka yang lebih pendek, termasuk rekening pasar vang dan pinjaman semalam antar bank (interbank rate). Sedangkan M3 adalah komponen M2 ditambah sertifikat deposito. Sertifikat deposito merupakan deposito tabungan yang buktinya bukan dalam catatan buku tabungan melainkan, dalam bentuk surat atau sertifikat.

Indeks Produksi Industri (IPI) menurut Rosidi (2000:1) merupakan sebuah indikator makroekonomi yang berfungsi sebagai monitoring suatu pergerakan dan fluktuasi dari segi sektor produksi industry pada ekonomi Indonesia. IPI mempunyai dua jenis yang saling terkait yaitu, Indeks Produksi Industri triwulan yang berfugsi sekaligus sebagai produksi industry serta estimasi sektor produksi industry untuk perhitungan kumulatif nasional dan Indeks Produksi Industi bulanan.

Pada dasarnya Indeks Produksi Industri (IPI) merupakan indikator yang dirilis oleh dewan US federal Reserve Bank untuk mengukur perubahan nilai total inflasi yang disesuaikan dengan output produksi dari produsen, perusahaan pertambangan, listrik, pasokan air dan industry gas. Industry konstruksi tidak termasuk dalam indeks ini. IPI bertujuan untuk mengukur kenaikan dan penurunan hasil produksi. Indeks Industri Produksi dirilis 
Ghassani, et al/Jurnal Ekonomi Syariah Teori dan Terapan Vol. 6 No. 2 Februari 2019: 372-385; PENGARUH VARIABEL MAKROEKONOMI TERHADAP JAKARTA ISLAMIC INDEX (JII) PERIODEJANUARI 2004 HINGGA DESEMBER 2017

ke pasar setiap bulannya, sekitar 16 hari setekah bulan yang dikaji telah berakhir.

Tiryaki (2017:316) menggambarkan adanya hubungan yang positif dan signifikan antara nilai tukar terhadap pengembalian saham di Turkey. Karena Turkey memiliki economy yang bergantung pada barang setengah jadi sehingga mata vang lira terapresiasi dan menyebabkan menurunnya biaya impor sehingga dapat mengurangi biaya produksi. Penelitian Sakti (2013) menghasilkan hubungan jangka panjang yang positif antara nilai tukar terhadap Jakarta Islamic Index.

Pada dasarnya nilai tukar mempengaruhi keputusan investor untuk berinvestasi. Ketika kurs pada mata vang domestic mengalami peningkatan (apresiasi) maka akan mendorong naiknya harga saham. Karena para investor akan merasa lebih menguntungkan untuk berinvestasi di dalam negeri dibandingkan dengan investasi di luar negeri (Antonio, 2013:78)

Dalam penelitian yang dilakukan oleh Sakti (2013:78) dan Kassim (2017:69) menyatakan bahwa adanya hubungan yang positif antara indeks produksi industry terhadap indeks saham syariah di Indonesia maupun di Malaysia.

Hubungan yang positif antara indeks produksi industry dengan harga saham mencerminkan kondisi ekonomi di masa depan. Ketika sektor riil suatu negara mengalami peningkatan akan mempengaruhi kenaikan IPI kemudian perusahaan akan memperbaiki kinerja perusahaan yang akan menyebabkan naiknya profitabilitas suatu perusahaan. Hal ini terjadi, karena para investor akan menanamkan sahamnya kepada perusahaan yang memiliki kinerja yang baik dengan tingkat profitabilitas yang juga tinggi. Karena perubahahan saat ini dalam produksi industry akan mempengaruhi arus kas perusahaan di masa depan.

Penelitian Kumar (2017:202) yang berjudul "Dynamic Linkages Between Macroeconomic Factors and Islamic Stock Indicies in a Non-Islamic Country India" didapatkan hasil penelitian yang menunjukkan bahwa adanya hubungan yang positif pada jumlah vang beredar terhadap pengembalian saham di India. Hal itu akan mengarah pada stimulus ekonomi yang akan menghasilkan pendapatan perusahaan sehingga akan menghasilkan naiknya indeks harga saham. Penelitian dengan hasil yang serupa ditemukan pada Kassim(2017:68) bahwa adanya hubungan yang positif antara money supply (M2 ataupun M3) terhadap saham syariah di Malaysia.

Dalam penelitian ini akan dirumuskan hipotesis sebagai berikut:

$\mathrm{H1}$ : Nilai Tukar berpengaruh signifikan terhadap indeks saham di Jakarta Islamic Index (JII)

$\mathrm{H} 2$ : Indeks Produksi Industri (IPI) berpengaruh signifikan terhadap indeks saham di Jakarta Islamic Index (JII)

H3 : Jumlah Uang Beredar berpengaruh signifikan terhadap indeks saham di Jakarta Islamic Index (JII) 
Ghassani, et al/Jurnal Ekonomi Syariah Teori dan Terapan Vol. 6 No. 2 Februari 2019: 372-385; PENGARUH VARIABEL MAKROEKONOMI TERHADAP JAKARTA ISLAMIC INDEX (JII) PERIODEJANUARI 2004 HINGGA DESEMBER 2017

Berdasarkan uraian tinjauan teoritis dan empiris yang telah dijelaskan pada bagian sebelumnya maka model analisis dari penelitian ini adalah sebagai berikut: $J \| I_{i=1}=\beta_{0}+\beta_{1}$ KURS $_{i=1}+\beta_{2} \mid P I_{i=1}+\beta_{3} M_{2}$ $\mathrm{i}=1+\mu_{\mathrm{i}=1}$.

Dengan keterangan :

JII = Jakarta Islamic Index (JII)

KURS = Nilai Tukar

IPI = Indeks Produksi Industri

M2 = Jumlah Uang Beredar

$\beta-\quad=$ Konstanta

$\mu$ - $=$ Error term

$i=1 \quad=$ timeseries

Model analisis VECM dengan panjang lag $(p-1)$ adalah sebagai berikut:

$$
\begin{aligned}
& \Delta y_{t}=a e_{t-1}+\beta_{1} \Delta y_{t-1}+\beta_{2} \Delta y_{t-2}+\cdots+\beta_{p} \Delta y_{t-p+1}+ \\
& \varepsilon+\ldots \ldots \ldots \ldots \ldots \ldots \ldots . . . . . . . .2 .2)
\end{aligned}
$$

Keterangan :

$\Delta y_{+} \quad=$ vektor turunan pertama variabel dependen

$\Delta y_{t-1} \quad=$ vektor turunan pertama variabel dependen dengan lag ke-1

$e_{t-1}=$ error yang diperoleh dari persamaan regresi antara $\mathrm{Y}$ dan $\mathrm{X}$ pada lag ke-1 dan disebut juga ECT (Error Correction Term)

$\varepsilon_{\dagger} \quad=$ vektor residual

$a \quad=$ matriks koefisien kointegrasi

$\beta_{i} \quad=$ matriks koefisien variabel

dependen ke-i, dimana $i=1,2, . . p$

Identifikasi variabel

Terdapat dua jenis variabel yang digunakan dalam penelitian ini, yaitu fvariabel independen atau variabel bebas dan variabel dependen atau variabel terikat. Variabel-variabel tersebut dapat dijelaskan sebagai berikut:

1. Variabel independen (Variabel Bebas)Variabel independen menurut Sugiyono (2013:4) adalah Variabel yang mempengaruhi penyebab perubahan dalam variabel dependen. Variabel independen dalam penelitian ini terdiri dari tiga variabel yaitu: Nilai Tukar, Indeks Produksi Industri (IPI) dan Jumlah Uang Beredar (JUB).

2. Variabel dependen (Variabel Terikat)Variabel dependen adalah variabel yang nilainya dipengaruhi oleh variabel bebas atau independen. Variabel dependen sering disebut sebagai variabel output, kriteria, konsekuen (Anshori dan ISwati, 2009:58. Variabel dependen dalam penelitian ini adalah indeks saham syariah Indonesia yaitu Jakarta Islamic Index (JII).

\section{METODE PENELITIAN}

Pendekatan kuantitatif pada penelitian ini menggunakan metode VECM (Vector Error Correction Model) dengan menggunakan 4 (empat) variabel pengukuran, yaitu Nilai Tukar, Indeks Produksi Indusstri (IPI) dan Jumlah Uang Beredar (JUB). Dengan periode tahun yang digunakan adalah Januar 2004 hingga Desember 2017

VECM digunakan pada data nonstasioner yang diketahui memilliki hubungan kointegrasi. VECM harus memiliki data yang stasioner pada 
Ghassani, et al/Jurnal Ekonomi Syariah Teori dan Terapan Vol. 6 No. 2 Februari 2019: 372-385; PENGARUH VARIABEL MAKROEKONOMI TERHADAP JAKARTA ISLAMIC INDEX (JII) PERIODEJANUARI 2004 HINGGA DESEMBER 2017

diferensiasi pertama dan semua variabel harus mempunyai stasioner yang sama yaitu turunan pertama.

Tahapan yang digunakan dalam metode penelitian VECM antara lain, Uji Stasioneritas Data, Penentuan Lag Optimal, Uji Kointegrasi, Uji Kausalitas dan Pemodelan VECM (Vector Error Correction Model).

\section{HASIL PENELITIAN}

Uji Stasioneritas Data

Tabel 1.

Hasil Uji Stasioner Data

\begin{tabular}{|c|c|c|c|c|}
\hline Var. & ADF & $\begin{array}{c}\text { Value } \\
5 \%\end{array}$ & Prob. & Ket. \\
\hline JII & -2.011 & -2.886 & 0.219 & $\begin{array}{c}\text { Tidak } \\
\text { Stasioner }\end{array}$ \\
\hline $\begin{array}{c}\text { Nilai } \\
\text { tukar }\end{array}$ & -0.876 & -2.886 & $\begin{array}{c}0.795 \\
7\end{array}$ & $\begin{array}{c}\text { Tidak } \\
\text { Stasioner }\end{array}$ \\
\hline IPI & -3.128 & -2.886 & $\begin{array}{c}0.024 \\
6\end{array}$ & Stasioner \\
\hline $\begin{array}{c}\text { JUB } \\
\text { (M2) }\end{array}$ & -0.903 & -2.886 & $\begin{array}{c}0.787 \\
1\end{array}$ & $\begin{array}{c}\text { Tidak } \\
\text { Stasioner }\end{array}$ \\
\hline
\end{tabular}

Sumber:: hasil uji STATA (diolah)

Berdasarkan hasil uji stasioneritas data diatas dapat diketahui bahwa nilai probabilitas pada masing-masing variabel memiliki nilai diatas critical value sebesar 0.05 atau $5 \%$ sehingga untuk melanjutkan penelitian diperlukan uji stasioneritas data turunan pertama, atau first difference.

Uji Stasioner Turunan Pertama

Tabel 2.

Hasil Uji Stasioner first difference

\begin{tabular}{|l|l|l|l|l|}
\hline Var & ADF & Value & Prob & Ket. \\
\hline
\end{tabular}

\begin{tabular}{|c|c|c|c|l|}
\hline JII & $\begin{array}{c}- \\
10.348\end{array}$ & -2.886 & 0.0000 & Stasioner \\
\hline $\begin{array}{c}\text { Nilai } \\
\text { tUkar }\end{array}$ & $\begin{array}{c}- \\
11.693\end{array}$ & -2.886 & 0.0000 & Stasioner \\
\hline IPI & $\begin{array}{c}- \\
17.515\end{array}$ & -2.886 & 0.0000 & Stasioner \\
\hline $\begin{array}{c}\text { JUB } \\
\text { (M2) }\end{array}$ & $\begin{array}{c}15.483 \\
\text { SUmb }\end{array}$ & -2.886 & 0.0000 & Stasioner \\
\hline
\end{tabular}

Sumber:: hasil uji STATA (diolah)

Setelah dilakukan uji stasioner pada turunan pertama, dapat dilihat pada tabel diatas bahwa semua variabel memiliki nilai probabilitas sebesar 0.0000 yang artinya semua data yang dimiliki telah stasioner sehingga dapat dilanjutkan pada tahap selanjutnya.

\section{Pemilihan Lag Optimal}

Pemilihan lag diperlukan untuk mengetahui lama periode respon pada variabel terhadap variabel masa lalu dan terhadap variabel independen. Penetuan lag ditentukan menggunakan pendekatan Likehood Ratio, Final Prediction Error, Akaike Information Criterion, Schwarz Information Criterion dan Hanan Quinn.

Hasil pemilihan lag pada penelitian ini menggunakan lag 1 karena adanya informasi pada masing-masing metode yang digunakan dan dibuktikan dengan tanda bintang $(*)$ pada hasil penelitian.

\section{Kointegrasi Johansen}

Tabel 3.

Uji Kointegrasi Johansen

\begin{tabular}{|c|c|c|c|}
\hline $\begin{array}{c}\text { Max } \\
\text { Rank }\end{array}$ & Eigenvalue & $\begin{array}{c}\text { Trace } \\
\text { Statistic }\end{array}$ & $\begin{array}{c}5 \% \\
\text { Critical }\end{array}$ \\
\hline
\end{tabular}


Ghassani, et al/Jurnal Ekonomi Syariah Teori dan Terapan Vol. 6 No. 2 Februari 2019: 372-385; PENGARUH VARIABEL MAKROEKONOMI TERHADAP JAKARTA ISLAMIC INDEX (JII) PERIODEJANUARI 2004 HINGGA DESEMBER 2017

\begin{tabular}{|c|c|c|c|}
\hline & & & Value \\
\hline 0 & - & 556.6882 & 47.21 \\
\hline 1 & 0.66933 & 372.9888 & 29.68 \\
\hline 2 & 0.64411 & 201.4872 & 15.41 \\
\hline 3 & 0.51237 & 82.2652 & 15.41 \\
\hline 4 & 0.39078 & - & 3.76 \\
\hline
\end{tabular}

Sumber:: hasil uji STATA (diolah)

Hasil kointegrasi Johansen dapat dijelaskan bahwa dalam taraf uji 0.05 atau $5 \%$ terdapat 5 rank variabel yang berhubungan kointegrasi. Dibuktikan pada nilai trace statistic 556.6882, 372.9888, 201.4872, dan 82.2652 lebih besar dari $0.05(\% \%)$ Critical Value yaitu, 47.21, 29.68, 15.41 dan 14.4. sehingga, dapat disimpulkan bahwa $\mathrm{HO}$ ditolak dan $\mathrm{H} 1$ diterima atau dengan kata lain, variabel-variabel yang digunakan memiliki hubungan dalam kointegrasi satu dengan lainnya. Adanya kointegrasi menujukkan bahwa diantara Jakarta Islamic Index (JII), nilai tukar, indeks produksi industry dan jumlah vang beredar $\left(M_{2}\right)$ memiliki hubungan stabilitas atau keseimbangan dan kesamaan pergerakan jangka panjang. Atau dengan kata lain dalam setiap periode jangka pendek seluruh variabel cenderung untuk saling menyeseuaikan untuk mencapai titik ekuilibrium pada jangka panjangnya.

\section{Estimasi VECM}

\section{Tabel 4.}

\section{Hasil Estimasi VECM}

\begin{tabular}{|l|l|l|l|l|}
\hline & Koef. & $\begin{array}{l}\text { Std. } \\
\text { Error }\end{array}$ & $\begin{array}{l}\mathrm{P}> \\
|\mathrm{z}|\end{array}$ & Ket \\
\hline Inkurs & -0.025 & 0.0116 & 0.031 & $\begin{array}{l}\text { Negatif } \\
\text { signifikan }\end{array}$ \\
\hline
\end{tabular}

\begin{tabular}{|l|l|l|l|l|}
\hline InIPI & 0.1074 & 0.0185 & 0.000 & $\begin{array}{l}\text { Positif } \\
\text { signifikan }\end{array}$ \\
\hline InM2 & 0.0474 & 0.0051 & 0.000 & $\begin{array}{l}\text { Positif } \\
\text { signifikan }\end{array}$ \\
\hline
\end{tabular}

Sumber:: hasil uji STATA (diolah)

Tabel estimasi VECM diatas dapat menjelaskan bahwa seluruh variabel memiliki probabilitas yang signifikan terhadap variabel Jakarta Islamic Index (JII). Dibuktikan dengan nilai probabilitas < 0.05 atau 5\%. Untuk koefisien pada variabel IPI dan JUB adalah positif, sedangkan variabel nilai tukar memiliki koefisien negatif.

Dapat disimpulkan bahwa variabel kurs terhadap JII memiliki hubungan yang positif dan signifikan. Variabel IPI terhadap JII memiliki hubungan yang positif dan signifikan. Dan variabel nilai tukar terhadap JII memiliki hubungan yang positif dan signifikan.

\section{PEMBAHASAN}

\section{Pengaruh Nilai Tukar Terhadap JII}

Berdasarkan hasil analisis yang dilakukan, diketahui bahwa adanya pengaruh negatif signifikan antara nilai tukar terhadap indeks harga saham Jakarta Islamic Index (JII). Hal ini menunjukkan bahwa fluktuasi nilai tukar yang tidak terkendali mempengaruhi penurunan pada indeks harga saham JII. Dengan demikian, dapat dikatakan bahwa nilai tukar menjadi salah satu faktor yang mempengaruhi pergerakan JII.

Hasil penelitian ini sejalan dengan hasil penelitian yang dilakukan oleh Sakti (2013) dan Kumar (2017) bahwa nilai tukar 
Ghassani, et al/Jurnal Ekonomi Syariah Teori dan Terapan Vol. 6 No. 2 Februari 2019: 372-385; PENGARUH VARIABEL MAKROEKONOMI TERHADAP JAKARTA ISLAMIC INDEX (JII) PERIODEJANUARI 2004 HINGGA DESEMBER 2017

memiliki hubungan yang negatif terhadap pengembalian saham.

Hal ini terjadi karena, Mata vang merupakan cerminan dari kondisi ekonomi suatu negara. Jika perekonomian suatu negara membaik, mata vang negara terserbut cenderung menguat terhadap mata vang negara lain. Apabila dollar menguat, rupiah akan melemah dan mengakibatkan para investor lebih memilik untuk berinvestasi dalam bentuk dollar dari pada dalam bentuk saham, sehingga investor akan melepaskan sahamnya. Apabila rupiah terapresiasi terhadap dollar akan menyebabkan para eksportir mengalami kerugian karena laba yang diperoleh akan berkurang dan menyebabkan keuntungan yang diperoleh juga berkurang.

\section{Pengaruh Indeks Produksi Industri terhadap JII}

Hasil analisis yang telah dilakukan menunjukkan bahwa Indeks Produksi Industri (IPI) mempunyai pengaruh yang positif signifikan terhadap JII. Hal tersebut menunjukkan bahwa salah satu faktor yang berperan dalam perubahan JII adalah Indeks Produksi Industri (IPI).

Hubungan yang positif antara indeks produksi industry dengan harga saham mencerminkan kondisi ekonomi di masa depan. Ketika sektor riil suatu negara mengalami peningkatan maka, akan mempengaruhi kenaikan pada IPI, perusahaan akan memperbaiki kinerja perusahaan yang berdampak pada meningkatnya profitabilitas perusahaan. Hal ini terjadi karena para investor akan menanamkan sahamnya kepada perusahaan yang memiliki kinerja yang baik dan dengan tingkat profitabilitas yang tinggi.

Hasil penelitian ini mendukung dengan penelitian yang dilakukan Tiryaki (2017), Sakti (2013) dan Kassim (2017) bahwa IPI memiliki hubungan yang positif terhadap harga saham di Turki, Indonesia dan Malaysia. Hal ini disebabkan karena meningkatnya aktivitas ekonomi riil akan menghasilkan laba yang tinggi pada perusahaan. Naiknya laba yang dihasilkan akan menyesuaikan kurva yang bergerak ke kanan dan menyebabkan harga saham meningkat. Hal ini jelas membuktikan bahwa arus kas pada perusahaan mencerminkan hubungan antara kegiatan industry dan harga saham syariah (Kassim, 2017).

\section{Pengaruh Jumlah Uang Beredar terhadap} JII

Hasil analisis yang telah dilakukan menunjukkan bahwa Jumlah Uang Beredar (M2) mempunyai pengaruh positif signifikan terhadap JII. Hal ini menunjukkan bahwa Jumlah Uang Beredar (M2) mervapak salah satu faktor yang berperan dalam perubahan JII.

Jumlah Uang Beredar (M2) dapat mempengaruhi harga saham ketika bertindak sebagai instrument selama proses transmisi kegiatan di sektor riil. Ketika pertumbuhan JUB mengalami pengingkatan akan mendorong masyarakat untuk menggunakan uang dalam barang dan atau jasa. Keinginan masyarakat yang tinggi akan 
Ghassani, et al/Jurnal Ekonomi Syariah Teori dan Terapan Vol. 6 No. 2 Februari 2019: 372-385; PENGARUH VARIABEL MAKROEKONOMI TERHADAP JAKARTA ISLAMIC INDEX (JII) PERIODEJANUARI 2004 HINGGA DESEMBER 2017

mengakibatkan meningkatnya arus kas perusahaan dan hal itu akan mengarah kepada meningkatnya harga saham perusahaan tersebut.

Hasil penelitian ini mendukung dengan hasil penelitian yang dilakukan oleh Kumar (2017), Kassim (2017). Menurut Kumar (2017) adanya hubungan yang positif pada jumlah vang beredar terhadap pengembalian saham akan mengarah pada stimulus ekonomi yang akan menghasilkan penningkatan pendapatan perusahaan, sehingga indeks harga saham perusahaan tersebut akan meningkat.

\section{SIMPULAN}

Berdasarkan analisi yang telah dilakukan, kesimpulan yang dapat diperoleh adalah

1. Hasil analisis menunjukkan bahwa nilai tukar berpengaruh secara negatif signifikan terhadap Jakarta Islamic Index (JII). Setiap pertambahan pada nilai tukar sebesar Rp. 1,00 akan menurunkan Jll sebesar 0.0251413 .

2. Hasil analisis menunjukkan bahwa indeks produksi industry berpengaruh secara positif signifikan terhadap Jakarta Islamic Index (JII). Setiap pertambahan indeks produksi industry sebesar satu satuan akan meningkatkan JII sebesar 0.1074576 .

3. Hasil analisis menunjukkan bahwa jumlah vang beredar (M2) berpengaruh secara positif dan signifikan terhadap Jakarta Islamic
Index (JII). Setiap pertambahan jumlah vang beredar sebesar satu milyar, maka akan meningkatkan Jll sebesar 0.0474157 .

\section{DAFTAR PUSTAKA}

Al-Bukhāri, Muhammad bin Isma'il Abu 'Abdillah. 1422H. Shahỉh al-Bukhāri juz 8 hal. 104. Beirut: Dārut Ṭūqi anNajah

Antonio, Syafii, Hafidhoh dan Himan. 2013. The Islamic Capital Market Volatility: A Comparative Between in Indonesia and Malaysia. Bulletin of Monetary, Economics and Banking

Anshori, Muslich dan Sri Iswati. 2009. Metodologi Penelitian Kuantitatif. Surabaya: Airlangga University Press (AUP)

an-Naisaburi, Muslim bin al-Hajjaj alQusyairi.Tanpa tahun.Șaḥị̣ Muslim juz 4 hal. 1996. Beirut: Dāru Inyā'it'turos

Arifin, Zainal. 2003. Dasar - Dasar Manajemen Bank Syariah. Jakarta: Alphabet

Aziz, Abdul. 2008. Ekonomi Islam :Analisis Mikro \& Makro. Yogyakarta: Graha IImu

Badan Pusat Statistik. Indeks Produksi Bulanan Industri Besar dan Sedang. Diakses melalui www.bps.go.id/statictable/2009/08 12/1061/indeks-produksi-bulananindustri-besar-dan-sedang.html tanggal 15 Oktober 2018

Bank Indonesia. Informasi Kurs Transaksi. Diakses melalui 
Ghassani, et al/Jurnal Ekonomi Syariah Teori dan Terapan Vol. 6 No. 2 Februari 2019: 372-385; PENGARUH VARIABEL MAKROEKONOMI TERHADAP JAKARTA ISLAMIC INDEX (JII) PERIODEJANUARI 2004 HINGGA DESEMBER 2017

www.bi.go.id/id/moneter/informasi

-kurs/transaksi-bi/ tanggal 10

Oktober 2018

. Uang Beredar dan Faktor-Faktor yang Mempengaruhinya. Diakses melalui

www.bi.go.id/id/statistik/seki/terkini Imoneter/ tanggal 10 Oktober 2018

Basuki, Agus Tri dan Nano Prawoto. 2016. Analisis Regresi dalam Penelitian Ekonomi dan Bisnis : Dilengkapi Aplikasi SPSS \& Eviews. Depok: PT. Rajagrafindo Persada

Beik, I. S,.\& Fatmawati. 2014. Pengaruh Indeks Harga Saham Syariah Internasional dan Variabel Makro Ekonomi Terhadap Jakarta Islamic Index. Al-lqtishad: Journal of Islamic Economics, 6(2), 155-178

Bursa Efek Indonesia. Laporan Tahunan IDX Statistics. Diakses melalui www.idx.co.id tanggal 16 November 2018

Dewan Syariah Nasional (DSN) Majelis Ulama Indonesia (MUI). 2001. Fatwa Pedoman Pelaksanaan Investasi Untuk Reksa Dana Syariah Departemen Agama Republik Indonesia. 2008. Al-Qur'an dan Terjemahan. Semarang CV. Toha Putra

Dunia Investasi. Indeks saham Syariah JII. Diakses melalui www.duniainvestasi.com tanggal 20 November 2018

El-Nader, Hassan M, dan Ahmad Diab. 2012. The Impact of Macroeconomic Factors on
Amman Stock Market Returns. International Journal of Economics and Finance, 4(12), 202.

Fatwa Dewan Syariah Nasional NO.20/DSN-MUI/VI/2001 Tentang Pedoman Pelaksanaan Investasi Untuk Reksa Dana Syariah.

Fatwa Dewan Syariah Nasional NO:80/DSN-MUI/III/2011 Tentang Penerapan Prinsip Syariah dalam Mekanisme Perdagangan Efek Bersifat Ekuitas Di Pasar Reguler Bursa Efek.

Gujarati, Damodar. 2003. Ekonometri Dasar. Terjemahan: Sumarno Zain. Jakarta: Erlangga.

Harris, R. 1995. Cointegration Analysis in Econometric Modelling. New York: Prentice Hall.

Huda, Nurul. 2007. Investasi Pada Pasar Modal Syariah. Jakarta: Kencana 2015. Lembaga Keuangan Islam: Tinjauan Teoritis dan Praktis. Jakarta: Kencana

S. Salim. H, dan Budi Sutisno. 2008. Hukum Investasi di Indonesia. Jakarta: Rajawali Pers.

L, Ahmet Tiryaki. 2017. The Causal Relationship Between Selected Macroeconomic Variables and Stock Returns in Turkey. Anandolu International Conference in Economics.

Kumar, Kiran, dan Bhawna Sahu. 2017. Dynamic Linkages Between Macroeconomic factors and Islamic. The Journal of Developing AreasVol.51 (1), pp 193-205. 
Ghassani, et al/Jurnal Ekonomi Syariah Teori dan Terapan Vol. 6 No. 2 Februari 2019: 372-385; PENGARUH VARIABEL MAKROEKONOMI TERHADAP JAKARTA ISLAMIC INDEX (JII) PERIODEJANUARI 2004 HINGGA DESEMBER 2017

Kuncoro, M. 2001. Manajemen Keuangan Internasional. Edisi Kedua. Cetakan Pertama. Yogyakarta: BPFE.

Krugman, Paul R. Maurice Obstffeld. 1999. Ekonomi Internasional Edisi ke Dua (terjemah). Jakarta, Erlangga

Manan, Abdul. 2016. Hukum Ekonomi Syariah: Dalam Perspektif Peradilan Agama. Jakarta: Kencana

Mannan, M. A. 1993. Understanding Islamic Finance: A Study of the Securities Market in an Islamic Framework. Islamic Research and Training Institute: Saudi Arabia

Metwally, M. 1995. Teori dan Model Ekonomi Islam. Jakarta: PT. Bangkit Daya Insana

Mishkin, Frederic S. 2008. The Economic Of Money, Banking and Financial Markets: Banking and Financial Markets. Jakarta: Salemba Empat.

Nasional, D. P. 2002. Kamus Besar Bahasa Indonesia. Jakarta: Balai Pustaka.

Otoritas Jasa Keuangan. Pasar Modal Syariah. Diakses melalui www.ojk.co.id pada 23 Septermber 2018

Rosidi, Ali. 2000. Industrial Production Index, Wholesale/Producer Index, Consumer Price Index of Indonesia. Country Paper fot the Joint OECD/ESCAP Workshop on Key Economic Indicators Bangkok, 2225 May 2000.

Sakti, M. R.P dan Yousuf Harun. 2013. Relationship Between Islamic Stock Prices and Macroeconomic Variables: Evidence from Jakarta
Stock Exchange Islamic Index. Global Review of Islamic Economics and Business Vol 1(1).

Shihab, Q.M. 2002. Tafsir Al-Mishbah. Jakarta: Lentera Hati

Sugiyono. 2012. Metode Penelitian Kuantitatif Kualitatif dan R\&D. Bandung: Alfabeta.

Sugianto, Dergibson, dan Sugiarto. 2000. Metode Statistika; Untuk Bisnis dan Ekonomi. Jakarta: Gramedia Pustaka Utama.

Sukirno, Sadono. 2013. Makroekonomi : Teori Pengantar.Jakarta : PT. Raja Grafindo Persada

Sunariyah. 2010. Pengantar Pengetahuan Pasar Modal, Edisi Ke Enam. Yogyakarta: UPP AMP YKP

Sutedi, Adrian. 2014. Pasar Modal Syariah Sarana Investasi Kevangan Berdasarkan Prinsip Syariah. Jakarta: Sinar Grafika

Soemitra, Andri. 2014. Masa Depan Pasar Modal Syariah di Indonesia. Jakarta: Kencana

Thobarry, A. 2009. Analisis Pengaruh Nilai Tukar, Suku Bunga, Laju Inflasi, dan Pertumbuhan GDP terhadap Indeks Harga Saham Properti (Kajian Empiris Pada BEl Periode Pengamatan 2000-2008). Jurnal Manajemen. Universitas Diponegoro.

Wahyudi, Imam dan Gandhi. 2014. Interdependence between Islamic Capital Market and Money Market: Evidence from Indonesia. Borsa Istanbul Review. 
Ghassani, et al/Jurnal Ekonomi Syariah Teori dan Terapan Vol. 6 No. 2 Februari 2019: 372-385; PENGARUH VARIABEL MAKROEKONOMI TERHADAP JAKARTA ISLAMIC INDEX (JII) PERIODEJANUARI 2004 HINGGA DESEMBER 2017

Widarjono, Agus. 2007. Ekonometrika Teori dan Aplikasi. Yogyakarta: Ekonisia FE UII. 